\title{
A Literature Review of Zika Virus
}

\author{
Anna R. Plourde, Evan M. Bloch
}

Zika virus is a mosquitoborne flavivirus that is the focus of an ongoing pandemic and public health emergency. Previously limited to sporadic cases in Africa and Asia, the emergence of Zika virus in Brazil in 2015 heralded rapid spread throughout the Americas. Although most Zika virus infections are characterized by subclinical or mild influenza-like illness, severe manifestations have been described, including Guillain-Barre syndrome in adults and microcephaly in babies born to infected mothers. Neither an effective treatment nor a vaccine is available for Zika virus; therefore, the public health response primarily focuses on preventing infection, particularly in pregnant women. Despite growing knowledge about this virus, questions remain regarding the virus's vectors and reservoirs, pathogenesis, genetic diversity, and potential synergistic effects of co-infection with other circulating viruses. These questions highlight the need for research to optimize surveillance, patient management, and public health intervention in the current Zika virus epidemic.

$\mathrm{Z}$ ika virus is a flavivirus that was first isolated in 1947 from a febrile rhesus macaque monkey in the Zika Forest of Uganda and later identified in Aedes africanus mosquitoes from the same forest (1). In 1954, the first 3 cases of human infection were reported in Nigeria (2). Serosurveillance studies in humans suggest that Zika virus is widespread throughout Africa, Asia, and Oceania (online Technical Appendix Table 1, http://wwwnc.cdc.gov/EID/ article/22/7/15-1990-Techapp1.pdf). However, these studies may overestimate the virus's true prevalence, given serologic overlap between Zika virus and related flaviviruses, such as dengue virus (DENV) and West Nile virus (WNV) $(3,4)$.

Historically, symptomatic Zika virus infections were limited to sporadic cases or small clusters of patients (online Technical Appendix Table 2). This pattern changed in 2007, when the first major outbreak of Zika virus infection occurred in Yap (Federated States of Micronesia), where $\approx 73 \%$ of the population were infected and symptomatic disease developed in $\approx 18 \%$ of infected persons (5). Since then, Zika virus infection has spread rapidly. Outbreaks have occurred in French Polynesia (6), Cook Islands (6), Easter Island (7), New Caledonia (8), and, most recently,

Author affiliations: University of California, San Francisco,

California, USA (A.R. Plourde); The Johns Hopkins University,

Baltimore, Maryland, USA (E.M. Bloch); Blood Systems Research Institute, San Francisco (E.M. Bloch)

DOI: http://dx.doi.org/10.3201/eid2207.151990 the Americas (9), with sporadic exportations to Europe (Figures 1-3; online Technical Appendix Table 2).

Zika virus was first reported in May 2015 in continental South America in Brazil, where $\approx 440,000-1,300,000$ persons have subsequently been infected (as of February 16, 2016). Furthermore, 29 other countries in the Americas have reported autochthonous Zika virus transmission, including Puerto Rico and US Virgin Islands (Figure 3; online Technical Appendix Table 2) (13). Except for 2 sexually acquired cases, Zika virus in the United States, Canada, and Europe has been restricted to travelers from affected areas (Figure 1; online Technical Appendix Table $2)$; a patient who delivered an infant with microcephaly in Hawaii had spent part of her pregnancy in Brazil (14).

Given the wealth of new information about Zika virus, we conducted a literature review to summarize the published findings. This review contextualizes the ongoing Zika virus epidemic in the Americas and identifies knowledge gaps that must be addressed to combat Zika virus successfully.

\section{The Review}

\section{Search Strategy and Selection Criteria}

Using the keywords "Zika," "ZIKV," "ZIKAV," and "Zika virus," we searched Google, PubMed, Web of Science, Scopus, and ProMed Mail. We reviewed all literature published through February 16, 2016, including peer-reviewed journal articles, infectious disease reporting system broadcasts, and public health agency information (e.g., US Centers for Disease Control and Prevention [CDC] and European Centre for Disease Prevention and Control [ECDC]). To ensure the capture of all information, we cross-referenced the bibliographies of reviewed articles. The search included English-language and foreign-language articles, which were computer translated.

\section{Virology and Pathogenesis}

Zika virus is a positive-sense single-stranded RNA virus in the family Flaviviridae, which includes several other mosquitoborne viruses of clinical importance (e.g., DENV, $\mathrm{WNV}$, and yellow fever virus [YFV]) (15). Its closest relative is Spondweni virus, the only other member of its clade $(15,16)$. The Zika virus genome contains 10,794 nt encoding 3,419 aa (16). Like other flaviviruses, Zika virus is composed of 2 noncoding regions ( $5^{\prime}$ and $3^{\prime}$ ) that flank an open reading frame (16), which encodes a polyprotein 


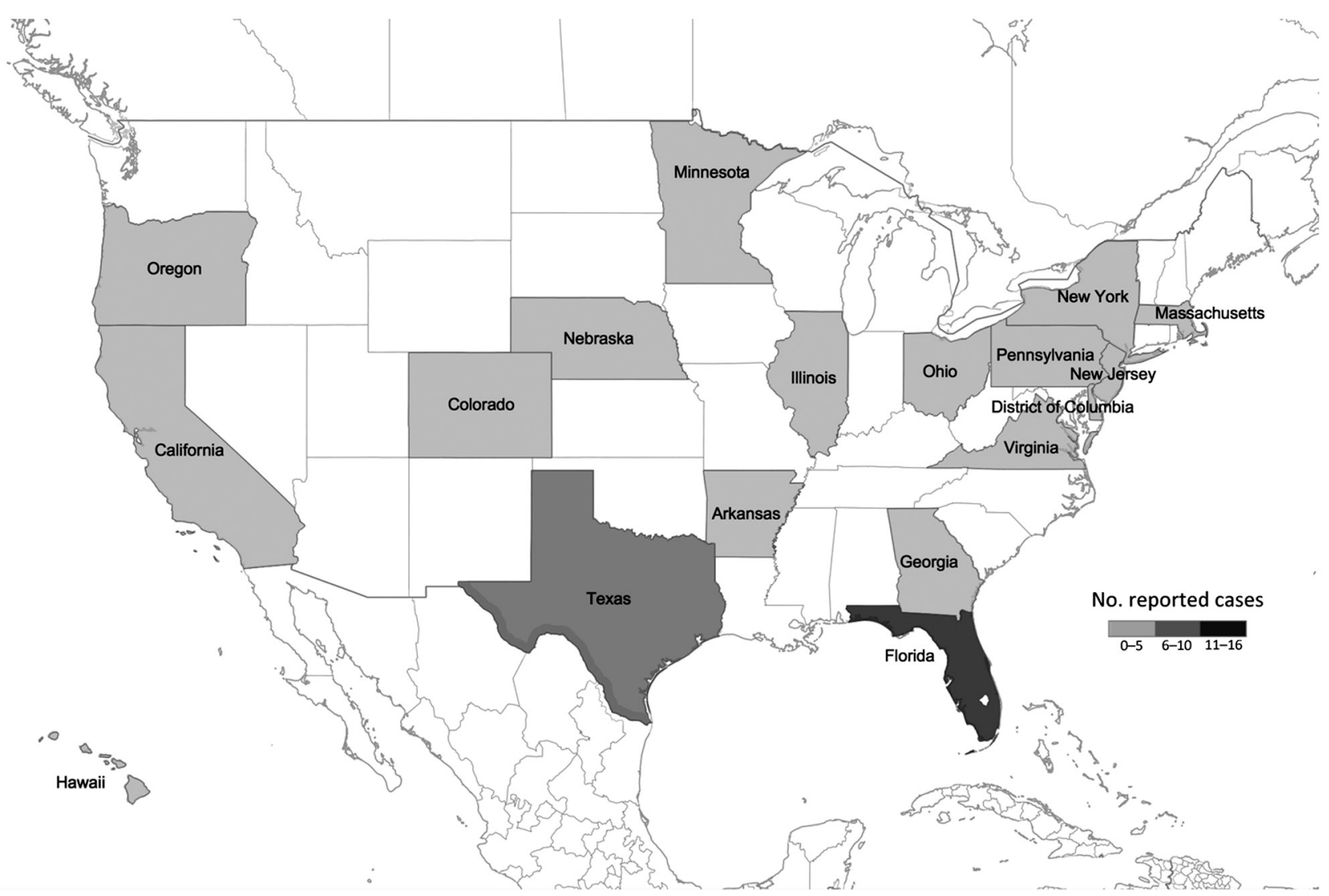

Figure 1. Cases of laboratory-confirmed, imported Zika virus infections in the United States, by state, January 1, 2015-February 10, 2016 (10). All cases are imported, with the exception of 2 sexually acquired autochthonous cases $(11,12)$.

cleaved into the capsid, precursor of membrane, envelope, and 7 nonstructural proteins (16).

Phylogenetic analysis shows that Zika virus can be classified into distinct African and Asian lineages; both emerged from East Africa during the late 1800s or early 1900s (17). The Asian lineage originated during the virus's migration from Africa to Southeast Asia, where it was first detected in Malaysia. From there, Zika virus spread to the Pacific Islands, separately to Yap and French Polynesia, and then to New Caledonia, Cook Islands, Easter Island, and the Americas (17).

A study of Zika virus's molecular evolution, based on viral strains collected from 4 countries in West Africa during 1947-2007, identified several sites within the Zika viral genome that were under strong negative selection pressure. This finding suggests frequent purging of deleterious polymorphisms in functionally important genes and the possibility of recombination, which occurs rarely among flaviviruses (18). The implications of this finding require further evaluation with respect to viral spread, zoonotic maintenance, and epidemiologic potential.

After mosquito inoculation of a human host, cellular entry likely resembles that of other flaviviruses, whereby the virus enters skin cells through cellular receptors, enabling migration to the lymph nodes and bloodstream. Few studies have investigated the pathogenesis of Zika virus infection. One study showed that human skin fibroblasts, keratinocytes, and immature dendritic cells allow entry of Zika virus (19). Several entry and adhesion factors (e.g., AXL receptor tyrosine kinase) facilitate infection, and cellular autophagy, needed for flaviviral replication, enhances Zika virus replication in skin fibroblasts (19). After cellular entry, flaviviruses typically replicate within endoplasmic reticulum-derived vesicles. However, Zika virus antigens were found exclusively in the nuclei of infected cells; this finding suggests a location for replication that differs from that of other flaviviruses and merits further investigation (20).

\section{Transmission}

Zika virus, like other flaviviruses, is transmitted by mosquitoes, primarily of the Aedes (Stegomyia) genus. Several Aedes spp. have been implicated, including Ae. aegypti, Ae. africanus, Ae. hensilli, and Ae. albopictus (1,21-23). The Ae. aegypti mosquito appears to be the major vector in Asia (24) and was the suspected primary vector for the French Polynesia outbreak (25). Zika virus has been detected in wild-caught 


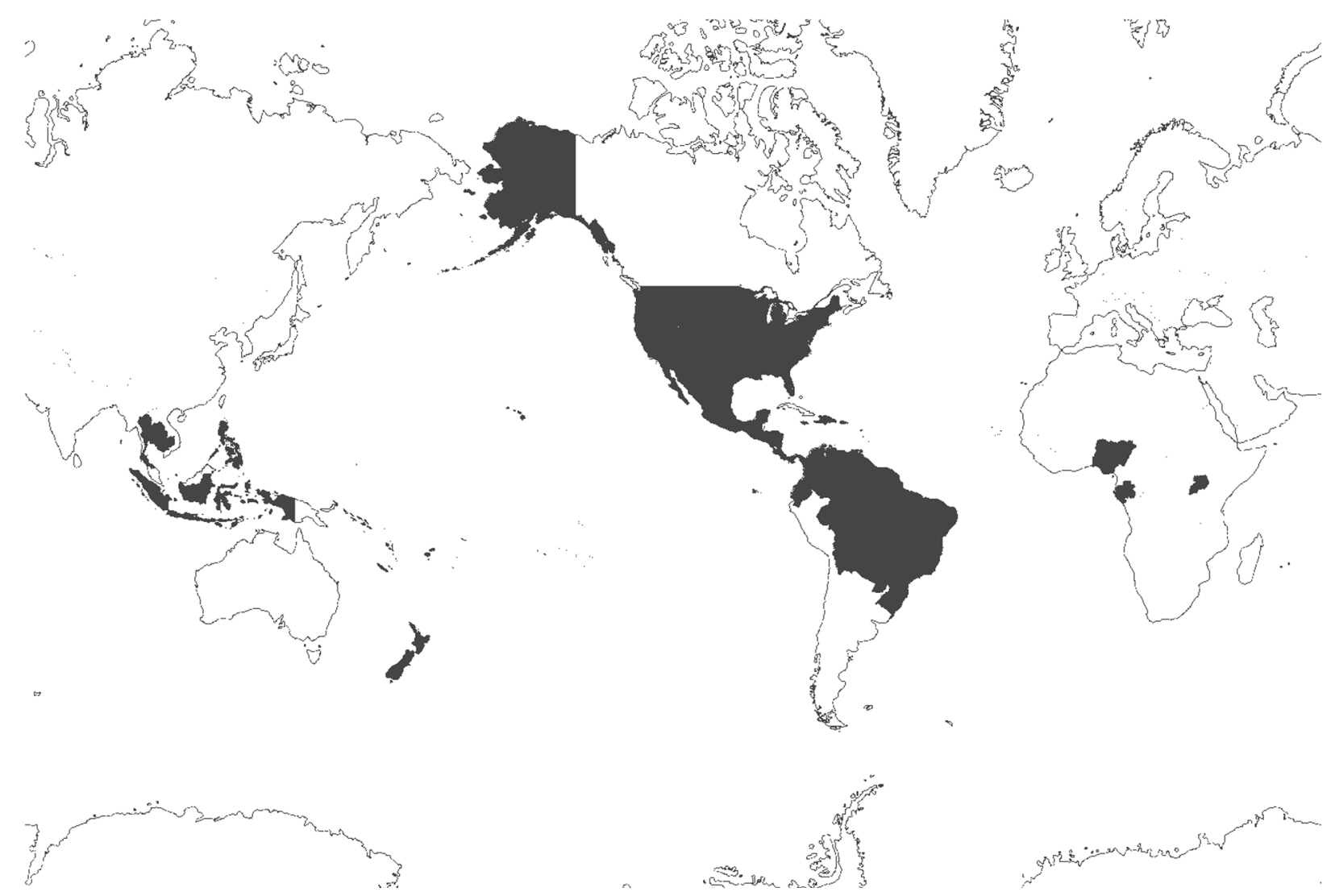

Figure 2. All countries and regions reporting laboratory-confirmed autochthonous Zika virus cases, January 1, 2015-February 10, 2016 (online Technical Appendix Table 2, http://wwwnc.cdc.gov/EID/article/22/7/15-1990-Techapp1.pdf). Data represent outbreaks and case reports for all reported autochthonous laboratory-confirmed cases of Zika virus infection, including those reported in the peer-reviewed literature; public health agency Web sites, bulletins, and broadcasts; and media reports for selected dates.

Ae. aegypti mosquitoes, which laboratory experiments have shown to be capable of transmitting Zika virus (26,27). Ae. hensilli mosquitoes were implicated in the Yap outbreak, yet Zika virus has never been isolated from these mosquitoes $(28,29)$. In Africa, the predominant Aedes species vector has not been definitively identified, although viral isolation studies suggest that Ae. albopticus was the likely vector in a 2007 Zika virus outbreak in Gabon (23).

Aedes mosquitoes are widely distributed globally, and native habitats of most species are warm tropical and subtropical regions (29-31). Some species show a limited distribution (e.g., Ae. luteocephalus in Africa and Ae. hensilli in the Pacific Islands); others have a broad geographic span (e.g., Ae. aegypti and Ae. albopictus) (29-31). Ae. albopictus does not yet appear to be a major vector of Zika virus. However, its role in the 2007 Gabon outbreak, its wide distribution throughout the United States, and Zika virus's lack of restriction to a specific Aedes sp. indicate that this species could serve as a vector in the United States (9).

Mosquito acquisition of the virus likely occurs during a blood meal; after uptake, the virus replicates and is transmitted to a reservoir animal at the next blood meal
(32). Isolation of the virus or of anti-Zika virus antibodies from various nonhuman primates and other wild and domestic animals suggests multiple animal reservoirs (33). One study examined the kinetics of Zika virus infectivity in Ae. aegypti mosquitoes by using blood-feeding membranes (27); viral content was high on the day of feeding (inoculation), decreased to undetectable levels through day 10 , increased by day 15 , and remained high on days 20-60. These findings suggest an incubation period in mosquitoes of $\approx 10$ days.

Other nonvector modes of Zika virus transmission include congenital (34), perinatal $(35)$, and sexual $(11,36)$. Possible transmission by blood transfusion $(37,38)$, animal bite (39), and laboratory exposure (40; online Technical Appendix reference 41) has been described; however, confounding by contemporaneous vectorborne transmission in these instances cannot be excluded. For example, the patient who became infected with Zika virus after a monkey bite had concomitant exposure to mosquitoes, a more plausible route of acquisition (39). Similarly, 1 of 2 patients with potentially laboratory-acquired infection (40; online Technical Appendix reference 41) reported recent 


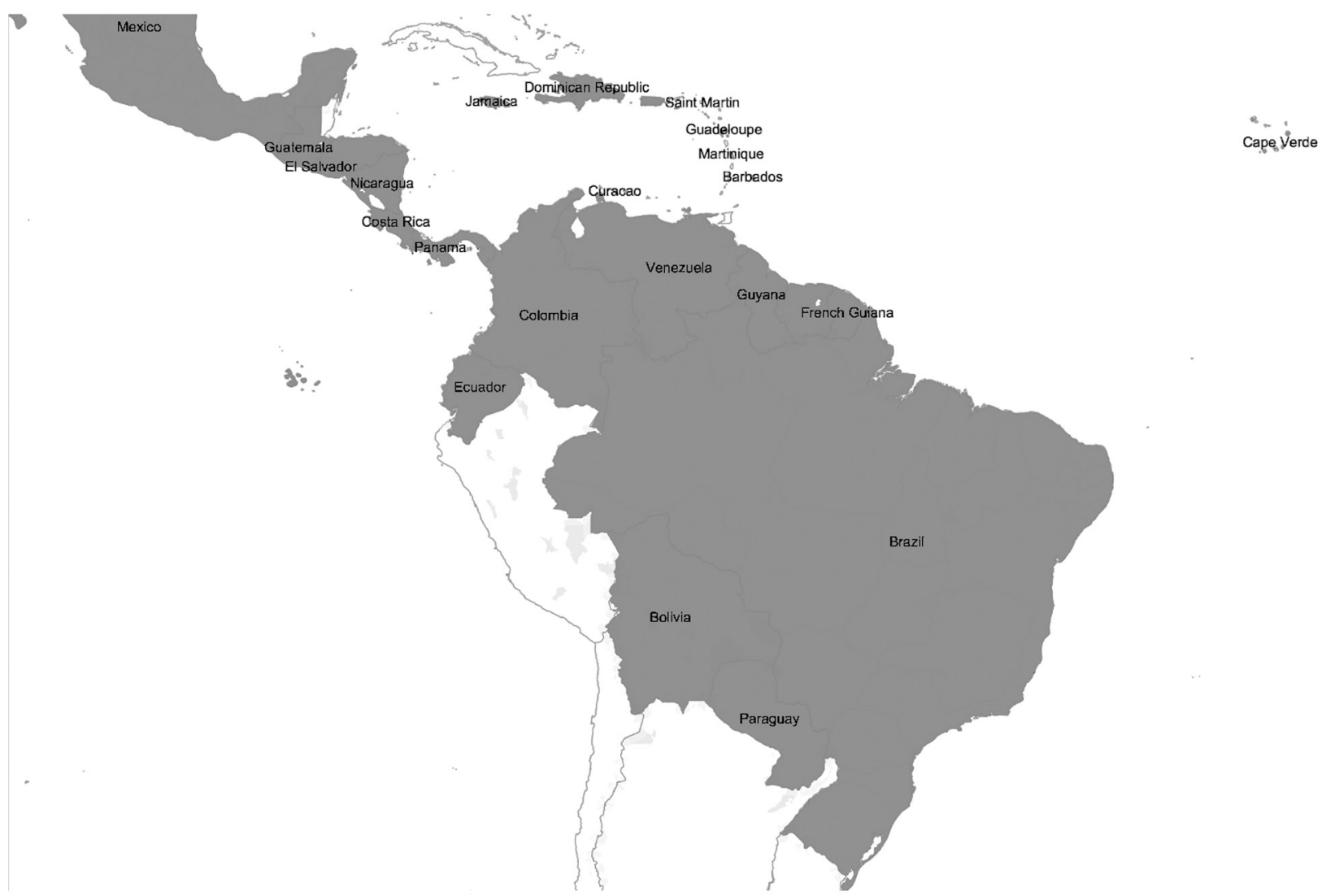

Figure 3. South America, Central America, and Caribbean countries and regions reporting laboratory-confirmed autochthonous Zika virus disease cases during January 1, 2015-February 10, 2016 (online Technical Appendix Table 2, http://wwwnc.cdc.gov/EID/ article/22/7/15-1990-Techapp1.pdf). Data represent outbreaks and case reports for all reported autochthonous laboratory-confirmed cases of Zika virus infection in these countries and regions during January 1, 1952-February 10, 2016, including those reported in peerreviewed literature; public health agency Web sites, bulletins, and broadcasts; and media reports.

exposure to mosquitoes (40); no definitive mechanism for transmission was described for either patient.

Intrauterine transmission is supported by the finding of Zika virus RNA by reverse transcription PCR (RT-PCR) in amniotic fluid of 2 mothers with symptoms of Zika virus infection during pregnancy; both delivered babies with microcephaly (34). Zika virus RNA has also been identified in tissue of fetuses from women infected during pregnancy and in brains of 2 live-born infants with microcephaly who died $<20$ hours after birth (online Technical Appendix references 42-45). Probable intrapartum transmission has also been described: 2 newborns were found to be viremic with Zika virus $\leq 4$ days after being born to infected mothers (35). Viral RNA, but not culturable virus, has been detected in breast milk (35), but transmission by breast-feeding has not been reported.

Two cases of possible transfusion-transmitted Zika virus were reported in Brazil (38). Furthermore, during the French Polynesia outbreak, a study found that $42(2.8 \%)$ of 1,505 asymptomatic blood donors were positive for Zika virus by RT-PCR; 11 donors described a Zika fever-like syndrome 3-10 days after donation (37).

\section{Clinical Manifestations}

In humans, the incubation period from mosquito bite to symptom onset is $\approx 3-12$ days. Infection is likely asymptomatic in $\approx 80 \%$ of cases $(5,32)$. All ages are susceptible (4 days-76 years), with a slight preponderance of cases in females (online Technical Appendix Table 3). When symptoms occur, they are typically mild, self-limiting, and nonspecific (online Technical Appendix Table 3); similarity to other arbovirus infections (e.g., DENV and chikungunya virus [CHIKV]) may confound the diagnosis (online Technical Appendix reference 46). Commonly reported symptoms include rash, fever, arthralgia, myalgia, fatigue, headache, and conjunctivitis (online Technical Appendix Table 3). Rash, a prominent feature, is maculopapular and pruritic in most cases; it begins proximally and spreads to the extremities with spontaneous resolution within 1-4 days of onset (40). Fever is typically low grade $\left(37.4^{\circ} \mathrm{C}-38.0^{\circ} \mathrm{C}\right)(8,36,40)$. Symptoms resolve within 2 weeks; accounts of longer persistence are rare (25; online Technical Appendix reference 47).

More severe clinical sequelae have increasingly been associated with Zika virus. During the ongoing outbreak 
in Brazil, reports of infants born with microcephaly have markedly increased ( $>3,800$ cases; 20 cases $/ 10,000$ live births vs. 0.5/10,000 live births in previous years) (online Technical Appendix reference 48). However, concern exists that these findings may in part be artifactual, resulting from previous underreporting of cases and confounding by other risk factors for microcephaly (online Technical Appendix reference 49). Because systematic surveillance for microcephaly was not previously undertaken, the baseline rate of microcephaly in Brazil is unknown, and subsequent reports suggest that a substantial proportion of infants that reportedly have microcephaly do not actually have the condition (online Technical Appendix reference 50).

Health officials in French Polynesia have reported an apparent increase in congenital central nervous system (CNS) malformations, coinciding with the outbreak occurring during 2013-2014 (online Technical Appendix reference 51). However, this finding should be cautiously interpreted; reports included only 17 cases, and none were laboratory-confirmed Zika virus cases. In addition, the true baseline rate of such malformations before the outbreak is unknown (online Technical Appendix reference 51).

A plausible neuropathologic link between Zika virus and CNS anomalies is supported by research showing viral neurotropism in intraperitoneally infected mice (online Technical Appendix reference 52) and progression of disease in directly infected mouse brains (online Technical Appendix reference 53). One hypothesis for Zika virus's role in CNS malformations pertains to the virus's hijacking of autophagy during viral replication (online Technical Appendix reference 54). Some cellular proteins have a dual role in autophagy and centrosome stability; a normal number of centrosomes is important for brain development (online Technical Appendix reference 54). An increase in centrosomes in mice has been shown to result in microcephaly (online Technical Appendix reference 54). Therefore, Zika virus's interference in autophagy has been hypothesized to lead to an increase in centrosome number and microcephaly; this potential role in malformations merits further investigation.

Severe neurologic sequelae have also been described in adults, including meningitis, meningoencephalitis, and Guillain-Barre syndrome (online Technical Appendix reference 55). A surge in Guillain-Barre syndrome cases has been observed in Brazil, Colombia, El Salvador, Suriname, Venezuela, and French Polynesia during outbreaks; however, Zika virus has been laboratory confirmed in only some of these cases (online Technical Appendix reference 55).

Nonneurologic sequelae include transient hearing loss, hypotension, and genitourinary symptoms $(11,36$; online Technical Appendix references 56,57). Hematospermia was reported in 2 cases $(11,36)$. A 44-year-old man in Tahiti in whom hematospermia developed 2 weeks after symptoms of Zika virus infection was found to have replicative cultured Zika virus particles in his semen (36). In addition, a 36-year-old man from the United States contracted Zika virus infection while in Senegal, and subsequently, his wife was infected in the United States; this case supports sexual transmission (11). A second sexually acquired case was reported in Texas (online Technical Appendix reference 58).

Rare deaths have been described in patients infected with Zika virus (online Technical Appendix reference 44). Besides 1 infant death, 3 other fatalities were reported (2 from Brazil and 1 from Colombia): 1 man with lupus erythematosus, chronic corticosteroid use, rheumatoid arthritis, and alcoholism; and 2 girls 16 years of age, 1 with sickle cell disease (online Technical Appendix reference 59). (Medical history was not reported for the other girl [online Technical Appendix reference 44].)

\section{General Laboratory Findings}

Information on laboratory findings for Zika virus infection is limited. Complete blood count is often normal; even if blood count is abnormal, changes may be nonspecific (e.g., mild lymphopenia, mild neutropenia, mild-to-moderate thrombocytopenia) ( 8 ; online Technical Appendix references 46,60-62). Mild elevations in inflammatory markers (C-reactive protein, fibrinogen, and ferritin), serum lactate dehydrogenase, or liver enzymes have been described $(8,25$; online Technical Appendix reference 57). These findings are observed in many other viral infections, including the co-circulating viruses DENV and CHIKV, so none of these laboratory alterations reliably distinguish among these infections.

\section{Diagnosis}

Clinical evaluation alone is unreliable for a diagnosis of Zika virus infection. Because of clinical overlap with other arboviruses, diagnosis relies on laboratory testing. Evaluation for Zika virus, CHIKV, and DENV should be undertaken concurrently for all patients who have acute fever, rash, myalgia, or arthralgia after recent (previous 2 weeks) travel to an area of ongoing Zika virus transmission (online Technical Appendix reference 63). Commercial assays have been developed, including a PCR-based assay that has been approved by the Communauté Européenne (RealStar Zika Virus RT-PCR Kit 1.0, altona Diagnostics, Hamburg, Germany) and a serologic assay that has been approved by the US Food and Drug Administration for restricted use in emergency situations (online Technical Appendix reference 64 ). Testing has typically been performed by large reference laboratories (e.g., US CDC and US state laboratories) and universities. CDC's typical turnaround time is 4-14 days. Appropriate tests are selected by the laboratory on the basis of clinical information provided by the requesting healthcare provider (online Technical Appendix reference 65). To coordinate sample collection, providers should contact local public health agencies before testing. 
Molecular amplification (e.g., RT-PCR) on serum samples remains the most specific diagnostic approach and is the preferred testing method for Zika virus during the acute phase of illness ( $<7$ days from symptom onset) (online Technical Appendix reference 63). In contrast, serologic testing is not recommended during the acute phase, when Zika virus IgM may be undetectable (22). However, molecular testing must be performed during the viremic period (15). Several case reports of negative RT-PCR results but positive IgM results for patients whose samples were tested at $\geq 5$ days after symptom onset indicate a possible viremic period as brief as 5 days $(25,36$; online Technical Appendix reference 61). Consequently, testing algorithms are based on sampling relative to symptom onset, and serologic testing should be considered if samples are negative for Zika virus by RT-PCR (online Technical Appendix reference 63).

Serologic testing has limitations. Zika virus IgM and IgG are notoriously cross-reactive with those against other flaviviruses (particularly DENV), limiting specificity $(5,15$; online Technical Appendix reference 46). Therefore, positive serologic test results should be confirmed with testing that uses an alternative platform such as a seroneutralization assay (e.g., plaque-reduction neutralization test) (22). However, flaviviral cross-reactivity can also pose problems in confirmatory assays, especially for patients immunized (e.g., against YFV or Japanese encephalitis virus) or infected with another flavivirus (e.g., WNV or St. Louis encephalitis virus); presence of antibodies confounds diagnosis (online Technical Appendix reference 63).

The type of sample can also affect the probability of detection. Although diagnostic testing is performed primarily on serum or cerebrospinal fluid, the diagnostic utility of other specimen types (e.g., urine, saliva, amniotic fluid, and tissue) is being evaluated (online Technical Appendix reference 63). Urine and saliva may offer alternatives, particularly when blood collection is difficult (e.g., in children or remote locations). Viruria may persist longer than viremia. One study reported that Zika virus RNA was detected in urine up to 20 days after viremia had become undetectable (online Technical Appendix reference 62); therefore, RT-PCR testing of urine should be considered when Zika virus is clinically suspected, despite negative serum testing $(22,33,35,36$; online Technical Appendix reference 62). Similarly, RT-PCR conducted with saliva has been shown to increase the detection rate during the acute phase of infection but does not extend the window of detection of Zika virus RNA; consequently, blood remains the preferred sample (online Technical Appendix reference 66).

\section{Management and Prevention}

No specific treatment or vaccine is available for Zika virus infection. Management is supportive and includes rest, fluids, antipyretics, and analgesics. Aspirin and other nonsteroidal antiinflammatory drugs should be avoided until dengue is excluded because of the risk for hemorrhage among dengue patients (online Technical Appendix reference 67).

Other general measures focus on prevention of mosquito bites, including individual protection (e.g., long pants, light-colored clothing, insect repellants, bed nets), particularly during known Ae. aegypti peak biting times (early morning and late afternoon) (online Technical Appendix reference 68). Community-level strategies target mosquito breeding through elimination of potential egg-laying sites (e.g., potted plant saucers, water storage units, used tires) by drying wet environments or using insecticide treatment (online Technical Appendix reference 68). Pregnant women residing in countries that are not Zika virus-endemic are advised against travel to affected countries (online Technical Appendix reference 69). Testing should be offered to all pregnant women who have traveled to areas with ongoing Zika virus transmission (online Technical Appendix reference 70). Serial fetal ultrasounds should be considered to monitor fetal anatomy and growth every 3-4 weeks in pregnant women with positive or inconclusive Zika virus test results, and the infant should be tested at birth (online Technical Appendix reference 70). Men who reside in or have traveled to an area of active Zika virus transmission and who have a pregnant partner should abstain from sexual activity or use condoms during sex; similar guidelines apply for men with a nonpregnant female sex partner who is concerned about sexual transmission of Zika virus (online Technical Appendix reference 58).

\section{Discussion}

Zika virus has been declared a public health emergency. As many as 1.3 million persons have been affected in Brazil alone (online Technical Appendix Table 2), and 20 countries or territories have reported local transmission of the virus during 2016 (Figures 2,3). Because of the ease of air travel and international trade, further spread into regions where the virus is not endemic is likely, and transmission is probable in locations with competent mosquito vectors. A robust, multifaceted response is underway that involves public health authorities, government agencies, the biomedical industry, medical practitioners, and researchers. However, uncertainty remains regarding aspects of the virus's vectors, epidemiology, and pathogenesis. As the epidemic unfolds, evaluating incoming data critically will be necessary to separate fact from speculation.

Foremost, diagnosis remains suboptimal. Diagnostic guidelines are contingent on laboratory testing that is not widely available. Although commercial tests for Zika virus are limited in number and availability, more are in development, including prototype multiplex molecular assays that concurrently test for Zika virus, CHIKV, and DENV 
(M.P. Busch, pers. comm.). However, although not unique to Zika virus, laboratory infrastructure and testing capability is lacking in resource-constrained settings where Zika virus is most prevalent.

Prevention measures (specifically, vector control) are a current priority, pending advances in diagnostics; the World Health Organization and the Pan American Health Organization have issued recommendations (online Technical Appendix reference 44). In the United States, multiple factors guard against the explosive epidemic occurring throughout Central and South America. Specifically, lower rates of human crowding in urban areas, wider access to air conditioning and mosquito repellants, and waste management limit mosquitoborne transmission, which has been the case for DENV (online Technical Appendix reference 71). Nonetheless, further entomologic research is needed to define the range of Zika virus vectors and identify new areas where autochthonous transmission could take place to enable early intervention. Investment is also needed in durable control measures such as adaptable vaccine platforms for arboviruses; currently, no Zika virus vaccines are in advanced development (9).

Aspects of Zika virus pathogenesis remain unclear. Zika virus's association with neurologic sequelae, including potential neuropathophysiologic mechanisms, is being actively investigated. Continued epidemiologic study, combined with research involving animal models, will offer increased insight, which could spur novel prevention strategies (9). If confirmed, insights into the timing of infection relative to gestational outcomes will guide policy. In the interim, new cases of Zika virus infection should be monitored for complications, particularly in babies born to mothers residing in Zika virus-affected areas. The effects of Zika virus in other vulnerable clinical subsets (e.g., those who have concurrent conditions or are immunocompromised) also merit further investigation, as does co-infection or sequential infection by co-circulating viruses.

Given reports of possible transfusion-transmitted Zika virus, the pandemic also has implications for the blood supply within Zika virus-endemic and nonendemic regions. The US Food and Drug Administration recommends 28day deferral for blood donors with confirmed or suspected Zika virus infection (38). Donor screening by nucleic acid testing is being considered but will be challenging to implement because of high costs and regulatory considerations. Pathogen-reduction technology has shown efficacy for treatment of plasma (online Technical Appendix reference 72); however, absence of a licensed pathogen reduction technology for use in red cells, high incremental cost, and technical barriers render such technology an unlikely shortterm solution.

Zika virus has the propensity to infect large numbers of persons with severe consequences in some cases.
The epidemic has serious medical, ethical, and economic ramifications, particularly in countries where the resources for early diagnosis are lacking and potential intervention measures (e.g., contraception or termination of pregnancy) are discouraged or illegal (online Technical Appendix reference 73). Although autochthonous transmission in the United States is unlikely to match the scale of the epidemic in Central and South America, much about Zika virus and the way the pandemic will evolve are unknown. Continued vigilance is warranted, along with a concerted effort toward improving our understanding, management, and prevention of this emerging pathogen.

\section{Acknowledgments}

We thank Matthew L. Brandwein for his technical expertise in generating the figures.

Dr. Plourde is a resident physician in the Departments of Pathology and Laboratory Medicine at the University of California, San Francisco Medical Center. Her interests include public health microbiology and emerging infectious diseases.

Dr. Bloch is an assistant professor in the Department of Pathology and an associate director of the Transfusion Division at The Johns Hopkins University School of Medicine. His interests include neglected tropical diseases and transfusiontransmissible infections.

\section{References}

1. Dick GW, Kitchen SF, Haddow AJ. Zika virus. I. Isolations and serological specificity. Trans R Soc Trop Med Hyg. 1952;46:509_ 20. http://dx.doi.org/10.1016/0035-9203(52)90042-4

2. MacNamara FN. Zika virus: a report on three cases of human infection during an epidemic of jaundice in Nigeria. Trans R Soc Trop Med Hyg. 1954;48:139-45. http://dx.doi.org/10.1016/ 0035-9203(54)90006-1

3. Korhonen EM, Huhtamo E, Smura T, Kallio-Kokko H, Raassina M, Vapalahti O. Zika virus infection in a traveller returning from the Maldives, June 2015. Euro Surveill. 2016; 21:30107. http://dx.doi.org/10.2807/1560-7917.ES.2016.21.2.30107

4. Baba SS, Fagbami AH, Ojeh CK. Preliminary studies on the use of solid-phase immunosorbent techniques for the rapid detection of Wesselsbron virus (WSLV) IgM by haemagglutination-inhibition. Comp Immunol Microbiol Infect Dis. 1999;22:71-9. http://dx.doi.org/10.1016/S0147-9571(98)00003-4

5. Duffy MR, Chen TH, Hancock WT, Powers AM, Kool JL, Lanciotti RS, et al. Zika virus outbreak on Yap Island, Federated States of Micronesia. N Engl J Med. 2009;360:2536-43. http://dx.doi.org/10.1056/NEJMoa0805715

6. Roth A, Mercier A, Lepers C, Hoy D, Duituturaga S, Benyon E, et al. Concurrent outbreaks of dengue, chikungunya and Zika virus infections - an unprecedented epidemic wave of mosquito-borne viruses in the Pacific 2012-2014. Euro Surveill. 2014;19:20929. http://dx.doi.org/10.2807/1560-7917.ES2014.19.41.20929

7. Tognarelli J, Ulloa S, Villagra E, Lagos J, Aguayo C, Fasce R, et al. A report on the outbreak of Zika virus on Easter Island, South Pacific, 2014. Arch Virol. 2016;161:665-8. http://dx.doi.org/ $10.1007 / \mathrm{s} 00705-015-2695-5$

8. Dupont-Rouzeyrol M, O'Connor O, Calvez E, Daurès M, John M, Grangeon JP, et al. Co-infection with Zika and dengue viruses in 2 
patients, New Caledonia, 2014. Emerg Infect Dis. 2015;21:381-2. http://dx.doi.org/10.3201/eid2102.141553

9. Fauci AS, Morens DM. Zika virus in the Americas-yet another arbovirus threat. N Engl J Med. 2016;374:601-4. http://dx.doi.org/ 10.1056/NEJMp1600297

10. Centers for Disease Control and Prevention. Zika virus disease in the United States, 2015-2016. 2016 Feb 10 [cited 2016 Feb 17]. http://www.cdc.gov/zika/geo/united-states.html

11. Foy BD, Kobylinski KC, Chilson Foy JL, Blitvich BJ, Travassos da Rosa A, Haddow AD, et al. Probable non-vector-borne transmission of Zika virus, Colorado, USA. Emerg Infect Dis. 2011;17:880-2. http://dx.doi.org/10.3201/eid1705.101939

12. Dallas County Health and Human Services. DCHHS reports first Zika virus case in Dallas County acquired through sexual transmission. 2016 Feb 2 [cited 2016 Feb 8]. http://www.dallascounty.org/ department/hhs/press/documents/PR2-2-16DCHHS ReportsFirstCaseofZikaVirusThroughSexualTransmission.pdf

13. Hennessey M, Fischer M, Staples JE. Zika virus spreads to new areas-region of the Americas, May 2015-January 2016. MMWR Morb Mortal Wkly Rep. 2016;65:55-8. http://dx.doi.org/10.15585/ mmwr.mm6503e1

14. European Centre for Disease Prevention and Control. Zika virus disease epidemic: potential association with microcephaly and Guillain-Barré syndrome (first update). 2016 Jan 21 [cited 2016 Feb 3]. http://ecdc.europa.eu/en/publications/Publications/ rapid-risk-assessment-zika-virus-first-update-jan-2016.pdf

15. Lanciotti RS, Kosoy OL, Laven JJ, Velez JO, Lambert AJ, Johnson AJ, et al. Genetic and serologic properties of Zika virus associated with an epidemic, Yap State, Micronesia, 2007. Emerg Infect Dis. 2008; 14:1232-9. http://dx.doi.org/10.3201/eid1408.080287

16. Kuno G, Chang GJ. Full-length sequencing and genomic characterization of Bagaza, Kedougou, and Zika viruses. Arch Virol. 2007;152:687-96. http://dx.doi.org/10.1007/s00705-006-0903-Z

17. Gatherer D, Kohl A. Zika virus: a previously slow pandemic spreads rapidly through the Americas. J Gen Virol. 2016;97:26973. http://dx.doi.org/10.1099/jgv.0.000381

18. Faye O, Freire CC, Iamarino A, Faye O, de Oliveira JV, Diallo M, et al. Molecular evolution of Zika virus during its emergence in the 20(th) century. PLoS Negl Trop Dis. 2014;8:e2636. http://dx.doi.org/ 10.1371/journal.pntd.0002636

19. Hamel R, Dejarnac O, Wichit S, Ekchariyawat P, Neyret A, Luplertlop N, et al. Biology of Zika virus infection in human skin cells. J Virol. 2015;89:8880-96. http://dx.doi.org/10.1128/ JVI.00354-15

20. Buckley A, Gould EA. Detection of virus-specific antigen in the nuclei or nucleoli of cells infected with Zika or Langat virus. J Gen Virol. 1988;69:1913-20. http://dx.doi.org/10.1099/ 0022-1317-69-8-1913

21. Marchette NJ, Garcia R, Rudnick A. Isolation of Zika virus from Aedes aegypti mosquitoes in Malaysia. Am J Trop Med Hyg. 1969;18:411-5.

22. Hayes EB. Zika virus outside Africa. Emerg Infect Dis. 2009;15:1347-50. http://dx.doi.org/10.3201/eid1509.090442

23. Grard G, Caron M, Mombo IM, Nkoghe D, Mboui Ondo S, Jiolle D, et al. Zika virus in Gabon (Central Africa) - 2007: a new threat from Aedes albopictus? PLoS Negl Trop Dis. 2014;8:e2681. http://dx.doi.org/10.1371/journal.pntd.0002681

24. Olson JG, Ksiazek TG, Suhandiman, Triwibowo. Zika virus, a cause of fever in Central Java, Indonesia. Trans R Soc Trop Med Hyg. 1981;75:389-93. http://dx.doi.org/10.1016/ 0035-9203(81)90100-0

25. Oehler E, Watrin L, Larre P, Leparc-Goffart I, Lastere S, Valour F, et al. Zika virus infection complicated by Guillain-Barre syndrome - case report, French Polynesia, December 2013. Euro Surveill. 2014;19:20720. http://dx.doi.org/10.2807/1560-7917. ES2014.19.9.20720
26. Diallo D, Sall AA, Diagne CT, Faye O, Faye O, Ba Y, et al. Zika virus emergence in mosquitoes in southeastern Senegal, 2011. PLoS One. 2014;9:e109442. http://dx.doi.org/10.1371/ journal.pone.0109442

27. Boorman JP, Porterfield JS. A simple technique for infection of mosquitoes with viruses; transmission of Zika virus. Trans R Soc Trop Med Hyg. 1956;50:238-42. http://dx.doi.org/10.1016/ 0035-9203(56)90029-3

28. Musso D, Nilles EJ, Cao-Lormeau VM. Rapid spread of emerging Zika virus in the Pacific area. Clin Microbiol Infect. 2014;20:O595-6. http://dx.doi.org/10.1111/1469-0691.12707

29. Ledermann JP, Guillaumot L, Yug L, Saweyog SC, Tided M, Machieng P, et al. Aedes hensilli as a potential vector of Chikungunya and Zika viruses. PLoS Negl Trop Dis. 2014;8:e3188. http://dx.doi.org/10.1371/journal.pntd.0003188

30. Kraemer MU, Sinka ME, Duda KA, Mylne A, Shearer FM, Brady OJ, et al. The global compendium of Aedes aegypti and Ae. albopictus occurrence. Sci Data. 2015;2:150035. http://dx.doi.org/10.1038/sdata.2015.35

31. Gaffigan TVWR, Pecor JE, Stoffer JA, Anderson T. Systematic catalog of culicidae. Suitland (MD): Smithsonian Institution; Silver Spring (MD): Walter Reed Army Institute of Research; 2016 [cited 2016 Feb 10]. http://mosquitocatalog.org/

32. Ioos S, Mallet HP, Leparc Goffart I, Gauthier V, Cardoso T, Herida M. Current Zika virus epidemiology and recent epidemics. Med Mal Infect. 2014;44:302-7. http://dx.doi.org/ 10.1016/j.medmal.2014.04.008

33. Haddow AD, Schuh AJ, Yasuda CY, Kasper MR, Heang V, Huy R, et al. Genetic characterization of Zika virus strains: geographic expansion of the Asian lineage. PLoS Negl Trop Dis. 2012;6:e1477. http://dx.doi.org/10.1371/journal.pntd.0001477

34 Oliveira Melo AS, Malinger G, Ximenes R, Szejnfeld PO, Alves Sampaio S, Bispo de Filippis AM. Zika virus intrauterine infection causes fetal brain abnormality and microcephaly: tip of the iceberg? Ultrasound Obstet Gynecol. 2016;47:6-7. http://dx.doi.org/10.1002/uog.1583135. Besnard M, Lastere S, Teissier A, Cao-Lormeau V, Musso D. Evidence of perinatal transmission of Zika virus, French Polynesia, December 2013 and February 2014. Euro Surveill. 2014;19:20751. http://dx.doi. org/10.2807/1560-7917.ES2014.19.13.20751

36. Musso D, Roche C, Robin E, Nhan T, Teissier A, Cao-Lormeau VM. Potential sexual transmission of Zika virus. Emerg Infect Dis. 2015;21:359-61. http://dx.doi.org/10.3201/eid2102.141363

37. Musso D, Nhan T, Robin E, Roche C, Bierlaire D, Zisou K, et al. Potential for Zika virus transmission through blood transfusion demonstrated during an outbreak in French Polynesia, November 2013 to February 2014. Euro Surveill. 2014;19:20761. http://dx.doi.org/10.2807/1560-7917.ES2014.19.14.20761

38. US Food and Drug Administration. Recommendations for donor screening, deferral, and product management to reduce the risk of transfusion transmission of Zika virus, recommendations for industry. 2016 Feb 16 [cited 2016 Feb 16]. http://www.fda.gov/ downloads/BiologicsBloodVaccines/GuidanceCompliance RegulatoryInformation/Guidances/Blood/UCM486360.pdf

39. Leung GH, Baird RW, Druce J, Anstey NM. Zika virus infection in Australia following a monkey bite in Indonesia. Southeast Asian J Trop Med Public Health. 2015;46:460-4.

40. Simpson DI. Zika virus infection in man. Trans R Soc Trop Med Hyg. 1964;58:335-8. http://dx.doi.org/10.1016/ 0035-9203(64)90201-9

Address for correspondence: Anna R. Plourde, University of California San Francisco, Departments of Pathology and Laboratory Medicine, 505 Parnassus Ave, San Francisco, CA 94143, USA; email:

anna.plourde@ucsf.edu 